\title{
Comparison between the U.S. and Another Country's Law of Privacy: Taking China and Britain for Example
}

\author{
Shi Hu \\ Law School \& Intellectual Property School, Sichuan University of Science \& Engineering
}

\begin{abstract}
The right of privacy is a basic personal right, which refers to the right that the interests of individual personality are not infringed, private affairs unrelated to the public interest are not allowed to be released to the public, and private territory belonging to individuals is not illegally invaded. The protection of the right to privacy stems from a basic belief: everyone has the right not to be disturbed, and has the right to decide how to appear in front of the public, unless they have taken the initiative to put themselves in the public view, or their privacy involves the public interest [1].
\end{abstract}

Keywords: Privacy, Public interest, Intrusion.

\section{Introduction}

Generally speaking, behaviors of infringing privacy mainly include the following forms: (a) unauthorized publication of private facts; (b) intrusion; (c) false lighting personal information, which may lead to defamation; (d) appropriation of an individual's name, portrait, voice, or other personal characteristic elements, which means an invasion of "appropriation"[2].

In the entertainment industry, fictional film and television works rarely involve the right of privacy, but documentary films, biographical films and historical films are likely to infringe upon the privacy of relevant people for involving the description of real people and events. Therefore, in the following sections, we will discuss three kinds of infringement of privacy, namely "unauthorized publication of private facts", "intruding into private territory" and "false lighting". Then, we will introduce the other two kinds of infringement of privacy, "defamation" and "invasion of Personal image right".

\section{The Publication of Private Facts without Authorization}

When it comes to the infringement dispute of "unauthorized publication of private facts", the plaintiff needs to prove the following legal requirements: first, the information disclosed belongs to personal privacy; Second, the defendant has a clear act of public disclosure; Third, the defendant's public act constitutes an offence and harassment to the plaintiff; Fourth, the personal privacy disclosed does not involve the public interest.

As far as the first point is concerned, the information disclosed should be "true" private facts or information concerning personal privacy. If the private information disclosed is false, the identification of the nature of infringement may not only be "unauthorized publication of private facts". The defendant may also constitute a false exposure, or even defamation infringement.
As far as "act of public disclosure" is concerned, although the specific means and methods for the defendant to disclose information are within the scope of the court's consideration, generally speaking, whether the defendant disclosed information through traditional media such as paper, magazines or television, or through new media such as personal websites, social websites, microblogs, whatsapp and other channels; Whether the defendant pastes a notice on the window of the street, or stands on the crowded street[3], or in a public restaurant to announce loudly[4], as long as the number of audience increases to a certain range, it can be regarded as public disclosure.

As for the third point "the degree of an offence and harassment to the plaintiff", American courts usually use the judgment standard of "the reaction of normal ordinary people under the same circumstances", rather than "the sensitivity of the plaintiff". In other words, whether the information disclosed has caused harassment to the plaintiff is not based on the subjective reaction of the plaintiff, but on whether normal ordinary people feel offended or harassed under the same circumstances. In actual cases, the U.S. courts generally believe that if the personal facts and information disclosed belong to "religion, sex, politics" and other areas, the defendant's disclosure of the above information should be deemed to have caused offense and harassment to the plaintiff.

One of the most important elements in judging whether the right of privacy has been infringed is whether the personal privacy disclosed involves the public interest. As we all know, there is no absolute right in the world. While protecting the right of privacy, the law should also give consideration to the public's right to know, the right to freedom of speech and the right to truthful report of the news media. Therefore, if the personal privacy disclosed also involves the public interest, such as the personal property of an official or the supervisor of a listed company and his/her family buy or sell shares of the company (which may involve "insider trading"), then any third party has the right to disclose the facts concerning personal privacy on the basis of public interest, and the behavior does not constitute infringement. In fact, in the cases 
of privacy infringement involving government officials, the U.S. courts without exception determine that the "public right to know" is far more important than the "personal right to privacy" of officials, and believe that government officials have the obligation to disclose their property, religious beliefs, political views and other private facts and information to the public, so as to ensure to protect public interests. In the following paragraphs, we will specifically introduce the free reporting right of the news media.

\section{The United States: Melvin v. Reid: "the Right to Pursue Happiness"}

Melvin v. Reid, which was tried by California court in 1931, is one of the classic cases involving infringement of personal privacy[5]. In this case, the plaintiff, Mrs. Merwin, formerly known as Gabrielle Darley, once worked as a prostitute and was the defendant in a murder case. After the court ruled that she was acquitted of a charge, Darley decided to give up the old business and change her name to marry Mr. Merwin, who was born in the upper class, and lived an enviable new life.

Seven years later, the defendant, a director made a film called The Red Kimono based on the real experience of Darley. It tells the story of Gabrielle Darley's experience before she was given a new life, including her becoming a prostitute and her suspected murder. For a moment, the life of Mrs. Merwin, who had changed her name, had to face the abandoned past again. Mrs. Merwin sued the director.

When hearing the case, District Court of Appeal defined "the right to privacy" as The right of privacy may be defined as the right to live one's life in seclusion, without being subjected to unwarranted and undesired publicity. In short, it is the right to be let alone. 21 R.C.L. 1197, 1198, but the Judge gave a negative answer to whether the defendant director's behavior violated the plaintiff's right to privacy. The Judge held that since the litigation information of Mrs. Merwin's murder case was publicly available, although the past events of Mrs. Merwin's are not unbearable to recall, those did not belong to "undisclosed private information", so the defendant did not infringe the plaintiff's privacy right.

However, the court still held that everyone has the right to "pursue and obtain happiness" according to the California Constitution. The court held that, "We believe that the publication by respondents of the unsavory incidents in the past life of appellant after she had reformed, coupled with her true name, was not justified by any standard of morals or ethics known to us, and was a direct invasion of her inalienable right guaranteed to her by our Constitution, to pursue and obtain happiness. Whether we call this a right of privacy or give it any other name is immaterial, because it is a right guaranteed by our Constitution that must not be ruthlessly and needlessly invaded by others. We are of the opinion that the first cause of action of appellant's complaint states facts sufficient to constitute a cause of action against respondents." In other words, the court held that it was "unnecessary" and "wanton trampling on social tolerance" that the defendant director used the plaintiff's prenuptial name in the plot and movie poster, thus ruled that the defendant violated the plaintiff's constitutional rights.

\section{China: Yang Jiang v. SUNGARI "Qian Zhongshu Manuscript" (2014 Beijing Higher Court)[6]}

In fact, this case involves two reasons: one is the lawsuit of copyright infringement, and the other is the lawsuit of privacy infringement. In this case, the plaintiff Yang Jiang, her spouse Qian Zhongshu, her daughter Yuan Qian and Li Guoqiang (the person not involved in the case) were originally friends. Yang Jiang, Qian Zhongshu and Qian Yuan had sent hundreds of private letters to Li Guoqiang. The letter was originally collected by Li Guoqiang, and then Li Guoqiang privately resold the above-mentioned letter to the defendant SUNGARI without the plaintiff's knowledge. The defendant announced in 2013 that it would auction the above private letters in public. Then the plaintiff filed a lawsuit for infringement of copyright and privacy.

When discussing whether the letters involved belong to the right of privacy of protection, Beijing No.3 Intermediate People's Court (Court of First Instance) held that the relevant letters involved were all private letters written by Qian Zhongshu, Yang Jiang and Yuan Qian to Li Guoqiang, and contents of the letters "includes academic discussions, life affairs, viewpoints, etc., which were personal information and private activities unrelated to public interests and belonged to the category of privacy", so they should be protected by law. As to whether the deceased person still enjoys the right to privacy or whether his family can exercise his rights on his behalf, Beijing No.3 Intermediate People's Court gave a positive reply, holding that "the deceased also has privacy, and the disclosure of the privacy of the deceased will inevitably bring stimulation and pain to the spirit of the close relatives of the deceased, and the close relatives of the deceased have personal interests related to the privacy of the deceased". In this regard, the Beijing Higher People's Court affirmed it in the second instance, and quoted Article 3 of the Interpretation of the Supreme People's Court on Certain Issues Concerning Determination of Liability for Compensation for Spiritual Damage Arising from Civil Tort, "When a close relative of a deceased natural person files an action with a people's court claiming compensation for mental distress due to any of the following acts of infringement, the people's court shall accept the action in accordance with the law: (a) infringement of the name, image, reputation, or honor of the deceased by insulting, libeling, disparaging, vilifying, or by any other means contrary to the social public interests or social morality; (b) infringement of the privacy of the deceased person by illegal disclosure or use of the privacy."

Therefore, the Beijing Higher People's Court held that the plaintiff Yang Jiang, as Qian Zhongshu's spouse and Qian Yuan's mother, had the right to request the infringer to bear the tort liability on behalf of the two close relatives after their death. To sum up, Beijing Higher People's Court ruled that the defendant's act of announcing the auction of the plaintiff's letters without the plaintiff's permission infringed the plaintiff's copyright and privacy.

\section{Intrusion}


In the entertainment industry, the news often comes from the paparazzi's tracking a shoot of celebrities or the informant's information (such as the information from the world-famous "Chaoyang masses"[7]). As the result, disclosure photos often lead to the protest of parties and the uproar of onlookers. In similar discussions, we often hear two voices, one voice denounces the paparazzi's disclosure behavior, holding that it violates the privacy of the parties; Another thinks that as a public figure, their right of privacy is limited compared with ordinary people. Especially when the shooting scene takes place in public places (such as hotel swimming pool, crowded street, restaurant), the person who is photographed and exposed has no right of privacy. So, which statement is more accurate in language?

First of all, intruding into the private territory without authorization is an act of infringing personal privacy. When the plaintiff brings a lawsuit, it needs to prove the following legal requirements: first, the infringement occurred in the plaintiff's private territory (such as the plaintiff's private residence[8], hidden hotel room[9], yacht cabin[10], etc.), in other words, the plaintiff has reasonable expectation of privacy when the events occurred in the above private territory. Second, the defendant intruded into the plaintiff's private territory by objects or in other forms, such as eavesdropping on the conversation of the parties through the installation of eavesdroppers[11], installing cameras in private residences or hotel rooms, or hacking the party's mailbox or website to steal private account information[12], etc.; Third, the above intrusion behavior is highly harassing for ordinary normal people. Similarly, the court will use "the sensitivity of ordinary normal people" to judge whether the invasion is "highly harassing", rather than just the "sensitivity" of the plaintiff.

At this point, the defendant can take the supervision right of the news media, the public's right to know and the related matters involving public figures and public interests as the defense. The following is to understand how U.S. courts attitude toward the infringement of "intruding into private territory" through several foreign cases.

\subsection{De Gregorio v. CBS, Inc.[13]: Filming in Public}

While plaintiff Carl De Gregorio, a construction worker and a female co-worker were walking along Madison Avenue holding hands one spring day, they were observed with interest by a CBS-TV camera crew filming a story about romance in New York City. The perceived novelty of these two hard-hats walking in romantic linkage apparently triggered the camera crew's interest in filming the couple.

The plaintiff was quickly approached by a woman from the CBS crew holding a microphone. She told the plaintiff about the photographic survey and asked him whether he wanted to make any comments for the show. Although Mr. De Gregorio may have felt warmly to his hard-hat compatriot, he had less than compassionate thoughts toward the TV crew. He demanded that the film be destroyed, advising the production manager that he was married and that his female co-worker was engaged to be married and that it would not "look good" to have a film of this hand-holding episode shown on TV.
The segment depicting Mr. De Gregorio and his female co-worker appeared on a May 10 and May 11, 1982 CBS-TV news broadcast entitled "Couples in Love in New York".

The plaintiff then sued CBS alleging invasion of privacy, intentional infliction of emotional distress, prima facie tort and defamation.

the New York court held that: In this case, the plaintiff's appearance lasted for approximately five seconds out of an approximately ten-minute broadcast. He was not identified by name; nor did he speak. I hold that his incidental, minor appearance does not constitute a violation of the Civil Rights Statute under consideration. Although the entire news broadcast was commercially sponsored, the plaintiff's picture was not utilized for advertising or trade purposes within the meaning of the New York Civil Rights Law Sec. 51, utilized for advertising or trade purposes. In Arrington v. New York Times, supra, 55 N.Y.2d 433, 449 N.Y.S.2d 941, 434 N.E.2d 1319 , the plaintiff's photograph was taken and used without his consent on the cover of The New York Times Magazine in connection with an article entitled "The Black Middle Class: Making It." The Court of Appeals stated that the photograph of the plaintiff was not a use "for the purpose of trade or advertising in the prohibition **925 of the statute ..." Id., 55 N.Y.2d at 440, 449 N.Y.S.2d at 944, 434 N.E.2d at 1321 (1982). The Court refused to permit Arrington to "vindicate a personal predeliction for greater privacy", concluding that "that may be part of the price every person must be prepared to pay for a society in which information and opinion flow freely." Id., 55 N.Y.2d at 442, 449 N.Y.S.2d at 945, 434 N.E.2d at 1322. In this case, plaintiff De Gregorio was filmed in a public place and can have no expectation of privacy in that location. Additionally, it does not matter that CBS may have earned a profit from the broadcast, for that fact does not alter their right to depict matters of public interest. Id., 55 N.Y.2d at 440,449 N.Y.S.2d at 944,434 N.E. $2 d$ at 1321 . It is the newsworthy aspect of the communication which is determinative rather than whether or not it was distributed commercially. And, where the communication is newsworthy, it may not be proscribed by Civil Rights Law, Secs. 50 and 51. Such is the case here. See Gautier v. Pro-Football, Inc., supra, 304 N.Y. at 359, 107 N.E.2d at 488.

\subsection{Wilkins v. NBC: "Hidden Lens" Shooting in Public[14]}

So, what are the regulations for "hidden lens" filming in public? In Wilkinson v. NBC, the defendant, a reporter from NBC secretly recorded the conversation of the whole lunch meeting with a pocket camera while having lunch with the plaintiff.

When deciding whether the defendant violated the plaintiff's privacy, the California Court held that the dining place was on the public terrace of Malibu beach restaurant, and the dining environment was not hidden; There are waiters walking around and guests dining across the table. Therefore, the plaintiff should not have the expectation of "high privacy" for the conversation in such an environment. The Court pointed out that if the plaintiffs want their conversation to be highly confidential, they can choose a more hidden office or private 
club rather than the terrace of a bustling public restaurant. Therefore, even if the defendant secretly recorded the whole conversation with a pocket camera, the defendant's behavior did not violate the plaintiff's privacy.

\subsection{Food Lion, Inc. v. Capital Cities ABC, Inc.[15]: "False Resume" and "Hidden Lens" Filming}

In the case of Food Lion, Inc. v. Capital Cities/ABC, Inc., the United States Court of Appeals for the Fourth Circuit in 1992, the court reached an interesting conclusion about the defendant's use of "hidden lens". In this case, in order to investigate the production quality of Food Lion's meat products, two reporters of $\mathrm{ABC}$ obtained the opportunity to work in Food Lion, Inc. by forging education background and recommendation letter, and secretly photographed the whole process of producing meat in the plaintiff's factory by using hidden cameras. After the defendant's program was broadcast, Food Lion's sales and share price of meat products fell, and the plaintiff filed a lawsuit.

In the trial of this case, the court of first instance held that the plaintiff's factory belonged to the plaintiff's private territory, while the defendant mixed up the plaintiff's factory by deception, which constituted several acts of infringement and breach of contract, such as fraud, unauthorized invasion of private territory and breach of loyalty treaty. Therefore, the court decided that the defendant's infringement was founded and should compensate the plaintiff's losses.

However, in the second instance, the Court of Appeals for the Forth Federal Circuit pointed out that although the defendant's behavior did violate the plaintiff's right to privacy, the news media should have the right to report the news freely, especially when the news involves the public interest. The court of appeals pointed out that the public has the right to know the truth and the news media also have the right to report truthfully because the process of processing meat in Lion Food, Inc. involves food safety issues. But the court also pointed out: enterprises also have the right to control the safe access to their plant; When recruiting employees, enterprises have the right to ask job seekers to provide true resumes; After employing employees, enterprises also have the right to ask employees to work seriously instead of damaging the business reputation of enterprises. Therefore, after balancing the interests of the public and the plaintiff, the court of Appeals ruled that the defendant's infringement of the plaintiff's private was established, but the amount of compensation was limited to two dollars.

\subsection{Murray v. Big Pictures[16]: Filming Minor Children of Public Figures}

In 2008, "Murray v. Big Pictures" involving the protection of the privacy rights of minor children of public figures was heard by the British court. Mrs. Maureen (pen name J.K. Rowling), author of the best-selling "Harry Potter", and her husband, Mr. Maureen filed the suit, in the name of their son David Maureen, who is only one and a half years old. The defendant is an organization that specializes in shooting and publishing photos of celebrities around the world. After getting the photo of Maureen's family walking on the road in the early morning, the defendant immediately published it in

\section{“Sunday Express" on April 3, 2005.}

In the photos involved, the Maureen couple pushed a stroller and walked on the streets of Edinburgh. The Maureen couple and their 19-month-old son can be clearly seen in the photo, including the clothes, size, hairstyle, hair color and skin color worn by their son David at that time. The photo was taken with a long focal length lens. The Maureen couple didn't realize that someone was taking a sneak shot at that time, and they didn't allow the photos involved to be published afterwards.

It is worth emphasizing that the Maureen couple did not claim to protect their own privacy rights in this case. On the contrary, they believe that the defendant's sneak shot violated his son David Maureen's privacy rights. In other words, the question that the British court needs to judge is "When the plaintiff himself is not a public figure, but a child of a public figure; When the shooting place belongs to a public place and there is no embarrassing or inappropriate scene in the shot picture, does the party enjoy the protection of the right of privacy?"

In this regard, the British court quoted previous cases, and pointed out that in disputes involving infringement of privacy rights, the first issue to be considered is whether the privacy claimed by the parties belongs to "the reasonable expectation of privacy protection". To evaluate this point, we should judge it by the standard of "reasonable ordinary people under normal circumstances". The second problem is how to balance the protection of privacy and the public's right to know.

As far as the first problem is concerned, the court held that it should be analyzed in the light of specific circumstances. If the couple involved in this case has taken the initiative to let their children appear or expose themselves in exchange for economic benefits, the scope for "the reasonable expectation of privacy protection" which their children demand for would be correspondingly reduced. But in this case, the Maureen couple never let their child in public. On the contrary, they are careful to avoid their child appearing in the public and media, hoping to give him a quiet and low-key childhood. The court held that according to the relevant United Nations treaties on child protection, the provisions of British domestic law and normal social customs, most parents do not want their minor children's photos to appear in the public media without permission. Therefore, the court held that David, the plaintiff in this case, enjoys the reasonable expectation of privacy protection.

On the second question, how to balance the privacy rights of minor children and the public's right to know, the court held that in this case, the privacy rights of the plaintiff David were more important, and believed that the defendant's taking and publishing the plaintiff's photos without authorized infringed David's right of privacy. Finally, the case was sent back for retrial.

From the above cases, it can be seen that under normal circumstances, if the paparazzi shoots in public places, such as the swimming pool of a hotel, the street, a restaurant, an airport or other public places where people come and go, then the court generally believes that the parties should not have 
reasonable expectations of the right of privacy. If you don't want to be seen or photographed by paparazzi, you should avoid doing some behaviors in places with higher concealment. However, in special circumstances, for the special protection of minors, when the parties involved in minors, even if events occur in public places, unauthorized shooting and publishing may also infringe the right to privacy.

\section{False Lighting}

False lighting refers to placing affairs unrelated on the parties, resulting in the wrong impression on the parties from the public. For example, if articles and interviews in the name of a writer spreading on the Internet, but in fact the writer has never written the above articles or received the above interview, it will constitute a "false lighting of personal information".

The earliest case about the false lighting of personal information is "Lord Byron v. Johnston" in 1816[17]. In this case, the plaintiff Lord Byron was a famous English poet, and the defendant Johnston published several poems in the name of Lord Byron. After the discovery of Lord Byron, he pointed out that some poems with the name of "Lord Byron" were not his own works, so he asked the court to grant an injunction against the defendants and to prohibit further distribution of these poems.

At present, a lot of "writer's quotations" and "celebrity interviews" spreading on the Internet are often not come out from the so-called writer/celebrity, but someone arbitrarily contributes a connection between the article/cause and an irrelevant writer/celebrity. In fact, all these behaviors are suspected of violating the right of privacy. When the situation of "false lighting" is serious enough to damage the reputation of the parties and there is a suspicion of defamation, it may constitute "defamation".

\section{Freedom of Speech of News Media}

As we all know, there is no absolute right in the world. While protecting the right of privacy, the law should also give consideration to the public's right to know, the right to freedom of speech and the right of truthful reporting of the news media. It's like two sides of a coin, seemingly opposite, but inseparable. Personality right is the most basic right that everyone enjoys, so everyone has the right to keep his privacy from being spied and disturbed by others. However, if the privacy of one person involves the public interest or the party concerned is a public figure, his right to privacy is bound to be limited.

\subsection{Public Figure}

So, what is "public figure"? There are two kinds of public figures: one is the famous people who enjoy a certain reputation and influence in related fields and are regarded as public figures by the public, such as movie stars, sports stars, government officials, etc; The other is a person who is not known, but because of an event that causes public attention to become a public figure, such as a criminal suspect, victim or witness in a criminal case[18].
With the development of American case law, the definition of public figure has become very extensive. Public figures can be government officials[19], actors[20], professional athletes[21], investment tycoons[22], explorers[23], war heroes[24], can also include soldiers[25] and other people.

Generally speaking, public figures do not enjoy the right of privacy; Or even if they enjoy the right of privacy, the scope of their right of privacy should be narrower than that of ordinary people. The reasons are as follows: first, most public figures voluntarily put themselves under the public view, and should broadcast their private life, personal preferences, schedule and circle of friends in exchange for popularity, influence and various interests. Therefore, when the public and the media are interested in their personal life, these public figures have nothing to complain about. After all, when public figures disclose information to attract public attention, they should be aware and prepared to lose some privacy. Second, the private affairs of some public figures have become public talks and public events after being exposed, and they have lost their privacy. Therefore, the affairs above should no longer be regarded as personal privacy. Third, the news media has the freedom to truthfully report public figures and events involving public interests, and the public also has the right to know. Therefore, based on the above reasons, courts in various countries often treat public figures as a special group when balancing personal privacy and freedom of speech of the news media. The court's different treatment towards public figures and ordinary people shows that it tries to seek a balance between the protection of privacy and freedom of speech.

\subsection{Public Interest}

Similarly, if an event involves the public interest, the media has the right to report it truthfully, and the public also has the right to know the truth of the matter. Events involving public interests are varied and almost cover all news contents reported by newspapers and magazines, such as political trends, international relations trends, military trends, stock fluctuations, banking policies, the promulgation and changes of laws and regulations, murders, hijackings, fires, floods and earthquakes, etc., all of which belong to events involving public interests of public concern.

It is worth mentioning that events involving public interests are not only limited to news events that are taking place, but also include events that have taken place but have historical significance. In other words, the freedom of reporting entitled by the news media and the freedom of speech entitled by the public are not limited to news reports, also exist in books, articles, movies, television, radio, dramas, paintings and various artistic creations as well.

In fact, criminal facts and personal information of criminals are not protected by privacy because they involve public interests. There was a heated debate on this issue in American courts in the middle of last century. Once upon a time, the U.S. Court held that the protection of privacy should also apply to the criminals who have been reformed, moreover, the court emphasized that the law should give them the opportunity to start a new life[26]. However, in the 1970s, the Supreme Court of the United States denied this view with a series of 
judgments. Although the victims and criminals in criminal cases entitles the right of privacy, the media also entitles the right of news reporting, and the public also entitle the right to know[27]. Therefore, after carefully balancing the right of privacy and the public interest, the Supreme Court of the United States made the following decision: if the media obtains the personal information of the criminal or the victim in a legal way or from public official information, then the media has the right to report truthfully and the public has the right to know the facts. In accordance with the above principles, during making documentaries about criminals, the United states media and production companies can directly use the official records of disclosing the personal information of criminals and other parties involved in criminal cases without the permission of the parties.

\section{References}

[1] Brandeis, L., \& Warren, S. (1890). The right to privacy. Harvard law review, 4(5), 193-220.

[2] Prosser, W. L. (1960). Privacy, 48 Calif. L. Rev, 383(10.2307), 3478805383.

[3] Brents v. Morgan, 221 Ky. 765, 299 S.W. 967 (1927)

[4] Bennett v. Norban, 396 Pa. 94, 151 A. 2d 476 (1959)

[5] Melvin v. Reid, 112 Cal. App. 285, 297 P. 91 (Cal. Ct. App. 1931)

[6] Wang Liming. (2019). On the pre-litigation injunction system for infringement of personality rights. Collection, 4.

[7] Li Haiyan. (2015). The story behind "Crowds of Chaoyang" and "Aunt Xicheng". Collection, 10.

[8] Young v. W. \& AR Co., 39 Ga. App. 761, 148 SE 414 (1929); Walker v. Whittle, 83 Ga. App. 445, 64 SE2d 87 (1951); Welsh v. Pritchard, 125 Mont. 517, 241 P. 2d $816(1952)$

[9] Id.

[10] Byfield v. Candler, 33 Ga. App. 275, 125 S.E. 905 (1924)

[11] McDaniel v. Atlanta Coca-Cola Bottling Co., 60 Ga. App. 92, 2 S.E.2d 810 (1939); Roach v. Harper, 143 W. Va. 869, 105 S.E.2d 564 (1958).

[12] Brex v. Smith, 104 N.J. Eq. 386, 146 A. 34 (Ch. 1929).

[13] De Gregorio v. CBS, Inc., 123 Misc. 2d 491, 473 N.Y.S. 2d 922 (Sup. Ct. 1984).

[14] Mumm, F. F. (2000). Recent Developments in the Law of Privacy. Comm. Law., 18, 3.

[15] Food Lion, Inc. v. Cap. Cities/ABC, ABC Holding Co., Am. Broad. Companies, Lynne Litt, Richard N. Kaplan, Ira Rosen, Susan Barnett, 951 F. Supp. 1211 (M.D.N.C. 1996).

[16] Cornish, W., Llewelyn, D., \& Aplin, T. (2003). Intellectual Property: Patents, Copyright, Trade Marks and Allied Rights (6 th). London, Sweet \& Maxwell.

[17] Dyer, G. (2020). Lord Byron's Trademark. ELH, 87(3), 679-705.

[18] Jones v. Herald Post Co., 230 Ky. 227, 18 S.W. 2d 972 (1929).

[19] New York Times Co. v. Sullivan, 376 U.S. 254, 84 S. Ct. 710, 11 L. Ed. 2d 686 (1964).

[20] Paramount Pictures v. Leader Press, 106 F.2d 229 (10th Cir. 1939).

[21] Ruth v. Educ. Films, 194 A.D. 893, 184 N.Y.S. 948 (App. Div. 1920).
[22] Corliss v. E.W. Walker Co., 64 F. 280 (C.C.D. Mass. 1894).

[23] Smith v. Suratt, 7 Alaska 416 (D. Alaska 1926).

[24] Stryker v. Republic Pictures Corp., 108 Cal. App. 2d 191, 238 P. 2d 670 (1951).

[25] Cont'l Optical Co. v. Reed, 119 Ind. App. 643, 86 N.E.2d 306 (1949).

[26] Briscoe v. Reader's Dig. Ass'n, Inc., 4 Cal. 3d 529, 483 P. 2d 34 (1971), overruled by Gates v. Discovery Commc'ns, Inc., 34 Cal. 4th 679, 101 P. 3d 552 (2004).

[27] Cox Broad. Corp. v. Cohn, 420 U.S. 469, 95 S. Ct. 1029, 43 L. Ed. 2d 328 (1975). 